\title{
GIS ANALYSIS OF LAND USE CHANGES - CASE STUDY: THE STARA PAZOVA MUNICIPALITY, SERBIA
}

\author{
Sanja Stojkovićk \\ "University of Belgrade - Faculty of Geography, Belgrade
}

\begin{abstract}
This paper examines land use changes on the territory of Stara Pazova municipality with an aim to describe the evolution of these changes and future trend. Lack of the reliable data about history of land use changes, which is one of the main problems in the similar researches in Serbia, was solved by using CORINE (Coordination of information on the environment) land cover database. The collected information and GIS analysis conducted under created geodatabase enable insight in spatial and temporal dimensions of these changes, identification of change types and assessment of their intensities. The obtained results indicate that trends of land use changes for the period 1990-2000 and 2000-2012 are very similar and point to tendency of agriculture land reduction and increasing of residential and industrial zones.
\end{abstract}

Key words: GIS analysis, land cover, Stara Pazova, changes trend.

\section{Introduction}

In the contemporary literature, researches in the field of land use changes analysis are becoming more and more present due to the fact that changes occurred on the land surface also affect the climate, ecosystem and its services (Brown et al., 2005; Chuai et. al., 2016; Pocewicz et al., 2008; Sharma et al., 2012; Song et. al., 2015; Sun and Li, 2017; Van der Sluis et. al., 2016;

${ }^{1}$ Corresponding author: S. Stojković, University of Belgrade - Faculty of Geography, Studentski trg 3/III, 11,000 Belgrade, Serbia; e-mail: sanja@gef.bg.ac.rs 
Vigl et. al., 2017). According to Srivastava et al. (2012) land use analysis and change detection are vital for the comprehension of global environmental processes transformation. Understanding of change patterns gives better basis for the projections of future changes trends. Land cover changes not only under human influences, but also changes naturally, and that are the reasons way the state of land cover is very dynamic. Very high land cover dynamics creates challenge of its mapping and keeping track of. As the intensive economic globalization continues, the trend of land use changes, environmental pollution, land degradation, etc. is also growing, which makes the timely and reliable land cover information necessary in order to mitigate the negative impacts on the environment (Ban et al., 2015).

Long time ago, remote sensing was recognized as an effective mean for land cover mapping (Kushwaha, 1990; Townshend et al., 1991; Cihlar, 2000) and now it represents a powerful tool for monitoring accelerated land use changes that are results of urban development (Alberti et al., 2004). Up to date, remote sensing and geographic information systems (GIS) are the best methods for studying spatial distributions and evolution of the geographic phenomenon in relation with land use and land cover changes, as for quantification of these changes (Popovici et al., 2013). Application of remote sensing and GIS in the assessment of land use changes are increasing during time (Asnawi and Choy, 2016; Gulinck et al., 2001; Mousazadeh et. al., 2015; Padonou et. al., 2017; Pasha et. al., 2016; Sabr et. al., 2016; Sari and Ozsahin, 2016; Serra et al., 2008; Waser and Schwarz, 2006).

The challenge faced by policy makers and scientists is the general lack of quality data about the types and extent of land use changes, and with even less systematic data of the causes and consequences of these changes. According to Loveland et al. (2002) lack of local, regional and national data of appropriate reliability and temporal and geographic details can lead to the unsuccessful assessment attempts of these changes implications.

The conducted research of recent land use changes on the territory of Stara Pazova municipality in this paper aiming to describe these changes and to give the trend of future changes. The land use maps for 1990, 2000 and 2012 year were created in order to quantify these changes. For the geodatabases production and for the changes analysis, GIS was used which also enables efficient visualization of obtained results. As Живковић and Јовановић (2007) stated contemporary development and spatial planning of human activities isn't feasible without appropriate cartographic representations. The aim of this study is to analyze main types of land use changes 
by using CORINE land cover databases and to identify and to investigate major factors that influenced these changes. The CORINE database is used for spatial analysis at different levels to assess the state of the environment (http://www.geosrbija.rs/). GIS application in this study enables and facilitates land use types visualization and its quantification, visualization of its changes and provides insight in spatial aspect of the land use changes in Stara Pazova municipality during period of 1990-2000 and 2000-2012.

\section{Study area}

The territory of Stara Pazova municipality is located in the east part of Srem and it is bordered by municipalities of Inđija on the north, Ruma on the west, Pećinci on the southwest, the river Danube on the east, and on the south it is leaning on the wider area of Belgrade city (Figure 1.) and covers the area of $351 \mathrm{~km}^{2}$. The municipality has nine settlements of which village settlements of compact type are Belegiš, Vojka, Golubinci, Krnješevci, a Pannonian-style farming settlement Stari Banovci, developed settlement of a Pannonian-style Nova Pazova, mixed settlement of a Pannonian-style Novi Banovci, a Pannonian-style farming-cattle settlement Surduk and urban settlement Stara Pazova (Ромелић, 2005). The status of local gravity center Stara Pazova gets based on the settlement size and due to the central position in the east part of Srem (Ћурчић, 2000). The population of Stara Pazova municipality grows up from 57,291 to 65,792 during period of 1991 to 2011 (http:/ / www.stat.gov.rs).

Land of the Stara Pazova municipality is flatland and fertile so it is suitable for different agriculture production, which is mainly economic activity of Srem wider area (hурчић et al., 1989). The most important infrastructure connections that are passing through the territory of Stara Pazova municipality are: A1 (the state border with Hungary - Novi Sad - Belgrade - Niš Vranje - the state border with BJR Macedonia) and A3 (the state border with Croatia - Belgrade) and the railways of international significance (directions the state border with Hungary - the state border with BJR Macedonia and section to the state border with Croatia).

The nearness of large city centers and economic impulses that are coming from there, favorable natural conditions for the agriculture development, positive migration balance and the most important state infrastructure corridors that are passing through municipality territory, defined the area of Stara Pazova municipality as a very dynamic and with a constant pressure on the land (Просторни план општине Стара Пазова до 2025. године, 2011). 


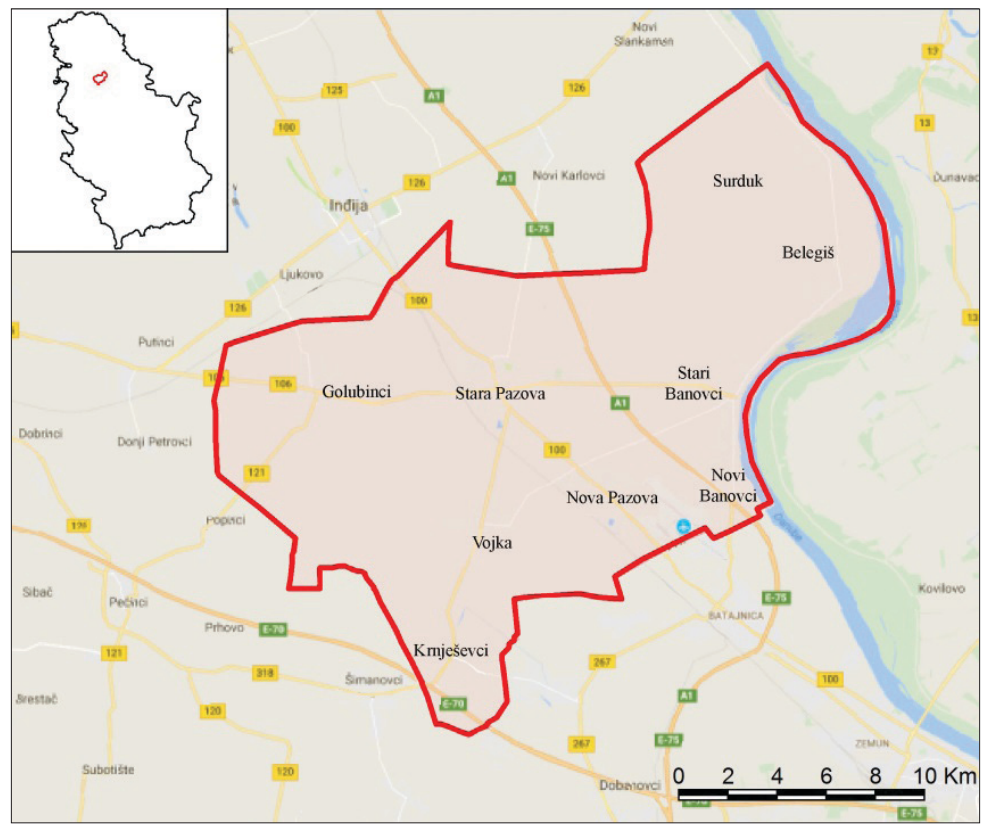

Figure 1 - Geographic position of the Stara Pazova municipality Source: https://www.google.rs/maps/

\section{Data and Methods}

For the purpose of the land use identification and classification in this study, layers of land cover generated within CORINE project were used. Data were collected within European Commission CORINE Programme for the purpose of development of environmental information system in Europe. Referent year for the first inventory was 1990, the first update was in 2000 and following update cycle is on six years. The program is coordinated by the European Environmental Agency in the framework of the EU Copernicus Programme. Data from CORINE land cover (CLC) are generated by processing of high resolution satellite images and they provide information about land cover changes in the major part of Europe (Feranec et al., 2010). Polygonal entities represent state of land cover differentiated in 44 classes (the lowest third level of interpretation) in the scale of 1:100.000. Thematic accuracy of obtained layers is $85 \%$, and geometric accuracy is about $100 \mathrm{~m}$ (Feraneca et al., 2007). According to Килибарда et al. (2010) interest of developed societies is to generate land cover databases and to cartographic represent them, and CLC classes are recognized as fundamental referent data sets for the spatial analysis. 
For the purpose of this research geodatabase of the Stara Pazova municipality was created in the GIS software package GeoMedia Professional. As it was already pointed out, the main source of the geospatial data is CORINE database (http://land.copernicus.eu/pan-european/corine-land-cover) for the 1990, 2000 and 2012 year (CLC 1990, CLC 2000, CLC 2012). According to Chen et al. (2015), it is common to find inconsistency and imperfections in these databases due to errors that occur during satellite images processing and their classification. Considering that and in order to insure high quality of data, for the purpose of this paper verification of data from CORINE database was accomplished on the basis of available literature, field research and official statistics.

The used technics of changes detection are based on the comparison of land use polygons obtained separately for the every time period and they imply spatial overlay of each polygon and searching of their intersections. The map overlay method is used during evaluation faze of this research (Kliskey, 2000; Palo et al., 2005). This method enables that different cartographic layers overlap one over the other when it is necessary (Y1lmaz, 2010).

Spatial overlay of thematic maps, i.e. logical overlaps which a looking for the intersection of objects and phenomena with particular characteristics, as well as the map algebra is greatly facilitated by the use of GIS software (Stojković et al., 2015). Likewise, GIS application enables cartographic visualization of obtained results.

\section{Results and discussion}

Study area includes 13 different land cover types separated on the basis of CORINE database, including: discontinuous urban fabric; industrial or commercial units; road and rail networks and associated land; airport; arable land; complex cultivation patterns; land principally occupied by agriculture, with significant areas of natural vegetation; pastures; forests; transitional woodlandshrub; inland marshes; beaches, dunes, sands; and water courses (Figure 2.).

In order to increase representativeness and facilitate the analysis of land use changes in table 1. six types of land use is separated on the basis of CLC land cover types and emphasis is placed on identification of agricultural and forest land, infrastructure systems, residential, industrial or commercial zones and water surfaces. 

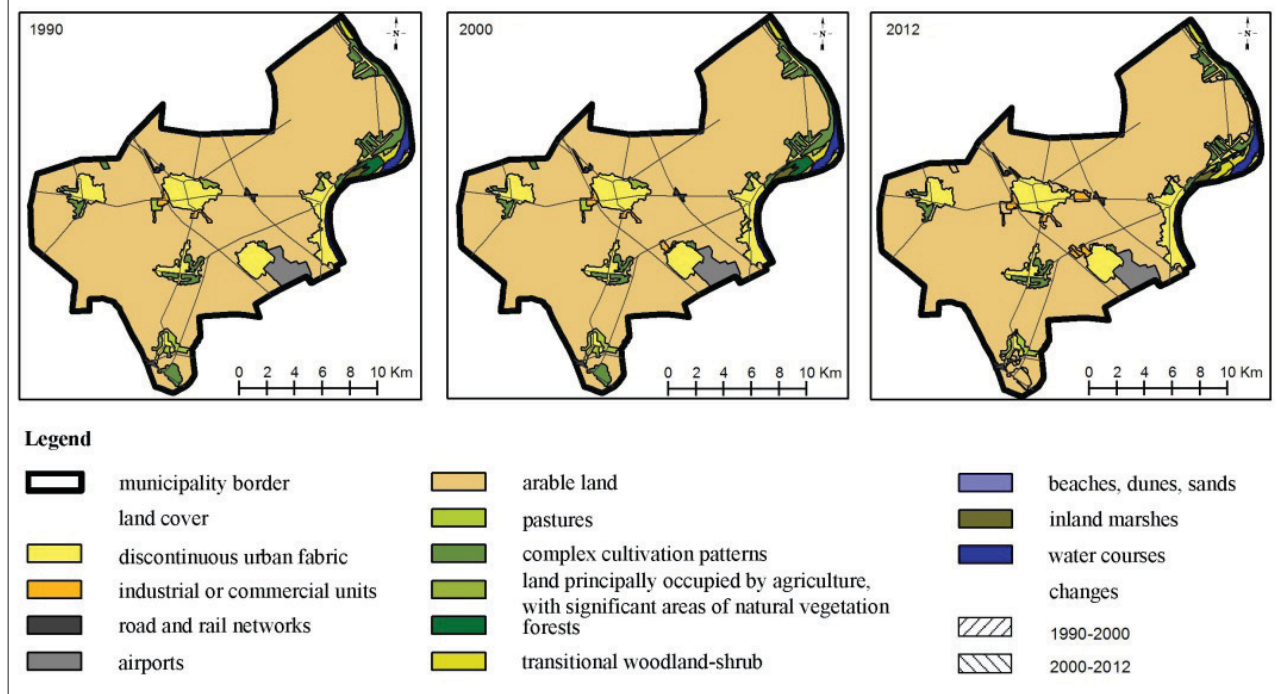

Figure 2 - Changes of land cover in the Stara Pazova municipality for the period 1990-2012.

The most represented type of the land use in Stara Pazova municipality during researched period is for the purpose of agriculture, residential and infrastructure systems, and then follows the surfaces under forest vegetation and industrial and commercial zones. Certainly, significant share in the total area has water surfaces, namely the river Danube which makes the east border of the study area.

Table 1 - Land use in the Stara Pazova municipality for the period 1990-2012.

\begin{tabular}{|l|c|c|c|c|c|c|}
\hline \multirow{2}{*}{ Land use types } & \multicolumn{7}{|c|}{ Area by years } \\
\cline { 2 - 7 } & in ha & in \% & in ha & in \% & in ha & in \% \\
\hline Residential zone & $2,774.17$ & 7.90 & $2,841.79$ & 8.10 & $3,012.72$ & 8.58 \\
\hline $\begin{array}{l}\text { Industrial or } \\
\text { commercial zones }\end{array}$ & 104.28 & 0.30 & 142.93 & 0.41 & 287.47 & 0.82 \\
\hline $\begin{array}{l}\text { Infrastructure } \\
\text { systems }\end{array}$ & 618.03 & 1.76 & 618.03 & 1.76 & 629.99 & 1.79 \\
\hline Agricultural land & $29,948.12$ & 85.32 & $29,841.85$ & 85.02 & $29,488.25$ & 84.01 \\
\hline Forests & 362.20 & 1.03 & 362.20 & 1.03 & 387.52 & 1.10 \\
\hline Water surfaces & $1,293.20$ & 3.68 & $1,293.20$ & 3.68 & $1,294.05$ & 3.69 \\
\hline
\end{tabular}


In the period 1990-2000 it was recorded change in agricultural land which was reduced for 106.27 ha, i.e. from $29,948.12$ ha $(85.32 \%)$ on $29,841.85$ ha $(85.02 \%)$. This change occurred due to increasing of residential zones for 67.62 ha (from $7.90 \%$ to $8.10 \%$ ) and industrial or commercial zones for 38.65 ha (from $0.30 \%$ to $0.41 \%$ ).

This trend of reducing agricultural areas continues and in the period $2000-2012$ in total amount of 353.6 ha, i.e. from $29,841.85$ ha $(85.02 \%)$ to $29,488.25$ ha $(84.01 \%)$. In this period reducing of agricultural areas also is consequence of increasing of residential zones for 170.93 ha (from $8.10 \%$ to $8.58 \%$ ), dramatic enhance of industrial or commercial zones for 144.54 ha (from $0.41 \%$ to $0.82 \%$ ), but also due to increasing of surfaces under infrastructure systems for 11.96 ha (from 1.76 to $1.79 \%$ ) and forest vegetation for 25.32 ha (from $1.03 \%$ to $1.10 \%$ ).

The obtained results indicate that three types of changes characterize the study area: urbanization and industrialization, agriculture abandoning and afforestation. The urbanization has trend of increasing during these two periods, which is in correlation with increasing number of inhabitants and sustainable economic growth of this territory. The development of industrial and commercial sector, as well as accompanying infrastructure systems are intensifying more and more as investments climate improves in whole country, that according to Vujadinović et al. (2016) influences on the economic growth and new jobs. The trend of increasing areas under the forest vegetation isn't so noticeable and is resulting from afforestation in the infrastructure systems close by (Просторни план општине Стара Пазова до 2025. године, 2011). Although, trend of agriculture abandoning is increasing, this is still the most dominant type of land use in the Stara Pazova municipality. At the end, it can be concluded that trends of land use changes in period 19902000 and 2000-2012 are very similar, and the major cause of these changes is development of industrial and commercial sector and greater urbanization.

\section{Conclusion}

The land use changes have an effect on the changes in the environment and the society in general. In this study the obtained information enable insight of the changes in the spatial and temporal dimensions, identification of the change types and estimation of the changes intensity. The research has shown that the territory of Stara Pazova municipality had undergone changes in the period between 1990 and 2012. The greatest influence was noticed on the agricultural areas which are reducing, as well as the 
consistent increasing of the urban areas in the researched period, which is the result of the growth of anthropogenic activities.

GIS analysis of land use changes during period 1990-2000 and 20002012, respecting the CORINE land cover database, has shown the modification extent of the land use change patterns, the mostly transition from one way of land use in the other. Also, GIS application facilitate the result visualization on the way that enables information about land use changes (in the volume and structure) and insight of the spatial distribution of these changes. The numerical and cartographic results of analysis represent consolidated overview of the land use change process in the Stara Pazova municipality. If some limitations and uncertainties of CORINE database (minimal mapping area is $25 \mathrm{ha}$ ) and possible mistakes during satellite images interpretation ignored, shown methodology can be reliable source for monitoring and quantification of spatial and temporal land use changes, especially on the national and regional level.

\section{Acknowledgements}

The paper is the result of the research within the project no. 176008 funded by the Ministry of Education and Science of the Republic of Serbia.

\section{References}

Alberti, M., Weeks, R. \& Coe, S. (2004). Urban Land-Cover Change Analysis in Central Puget Sound. Photogrammetric Engineering \& Remote Sensing, 70(9), 1043-1052.

Asnawi, N.H. \& Choy, L.K. (2016). Analysis of Land Use and Land Cover Changes in Gombak, Selangor Using Remote Sensing Data. Sains Malaysiana, 45(12), 1869-1877.

Ban, Y., Gong, P. \& Giri, C. (2015). Global land cover mapping using Earth observation satellite data: Recent progresses and challenges. ISPRS Journal of Photogrammetry and Remote Sensing, 103, 1-6.

Brown, D.G., Johnson, K.M., Loveland, T.R. \& Theobald, D.M. (2005). Rural land-use trends in the conterminous United States, 1950-2000. Ecological Applications, 15, 1851-1863.

Chen, J., Chen, J., Liao, A., Cao, X., Chen, L., Chen, X., He, C., Han, G., Peng, S., Lu, M., Zhang, W., Tong, X. \& Mills, J. (2015). Global land cover map- 
ping at 30 m resolution: A POK-based operational approach. ISPRS Journal of Photogrammetry and Remote Sensing, 103, 7-27.

Chuai, X., Huang, X., Wu, C., Li, J., Lu, Q., Qi, X., Zhang, M., Zuo, T. \& Lu, J. (2016). Land use and ecosystems services value changes and ecological land management in coastal Jiangsu, China. Habitat International, 57, 164-174.

Cihlar, J. (2000). Land cover mapping of large areas from satellites: status and research priorities. Int. J. Remote Sens., 21(6-7), 1093-1114.

Feranec, J., Jaffrain, G., Soukup, T. \& Hazeu, G. (2010). Determining changes and flows in European landscapes 1990-2000 using CORINE land cover data. Applied Geography, 30, 19-35.

Feraneca, J., Hazeub, G., Christensenc, S. \& Jaffraind, G. (2007). Corine land cover change detection in Europe (case studies of the Netherlands and Slovakia). Land Use Policy, 24, 234-247.

Gulinck, H., Mugica, M., Lucio, J.V. \& Atauri, J.A. (2001). A framework for comparative landscape analysis and evaluation based on land cover data, with an application in the Madrid region (Spain). Landscape and Urban Planning, 55, 257-270.

Kliskey, A.D. (2000). Recreation terrain suitability mapping: A spatially explicit methodology for determining recreation potential for resource use assessment. Landscape and Urban Planning, 52(1), 33-43.

Kushwaha, S.P.S. (1990). Forest-type mapping and change detection from satellite imagery. ISPRS J. Photogrammetry Remote Sens., 45, 175-181.

Loveland, T.R., Sohl, T.L., Stehman, S.V., Gallant, A.L., Sayler, K.L. \& Napton, D.E. (2002). A Strategy for Estimating the Rates of Recent United States LandCover Changes. Photogrammetric Engineering \& Remote Sensing, 68, 1091-1099.

Mousazadeh, R., Ghaffarzadeh, H., Nouri, J. Gharagozlou, A. \& Farahpour, M. (2015). Land use change detection and impact assessment in Anzali international coastal wetland using multi-temporal satellite images. Environ Monit Assess, 187: 776.

Padonou, E.A., Lykke, A. M., Bachmann, Y., Idohou, R., Sinsin, B. (2017). Mapping changes in land use/land cover and prediction of future extension of bowé in Benin, West Africa. Land Use Policy, 69, 85-92.

Palo, A., Aunap, R. \& Mander, U. (2005). Predictive vegetation mapping based on soil and topographical data: A case study from Saare County, Estonia. Journal for Nature Conservation, 13, 197-211. 
Pasha, S.V., Reddy, C.S., Jha, C.S., Prasada Rao, P.V.V. \& Dadhwal, V.K. (2016). Assessment of Land Cover Change Hotspots in Gulf of Kachchh, India Using Multi-Temporal Remote Sensing Data and GIS. J Indian Soc Remote Sens, 44(6), 905-913.

Pocewicz, A., Nielsen-Pincus, M., Goldberg, C.S., Johnson, M.H., Morgan, P., Force, J.E., Waits, L.P. \& Vierling, L. (2008). Predicting land use change: comparison of models based on landowner surveys and historical land cover trends. Landscape Ecology, 23, 195-210.

Popovici, E., Bălteanu, D. \& Kucsicsa, G. (2013). Assessment of Changes in Land-Use and Land-Cover Pattern in Romania Using CORINE Land Cover Database. Carpathian Journal of Earth and Environmental Sciences, 8(4), 195-208.

Sabr, A., Moeinaddini, M., Azarnivand, H. \& Guinot, B. (2016). Assessment of land use and land cover change using spatiotemporal analysis of landscape: case study in south of Tehran. Environ Monit Assess, 188: 691.

Sari, H. \& Ozsahin, E. (2016). Spatiotemporal Change in the LULC (Landuse/ Landcover) Characteristics of Tekirdag Province Based on the CORINE (Thrace, Turkey). Fresenius Environmental Bulletin, 25(11), 4694-4707.

Serra, P., Pons, X. \& Sauri, D. (2008). Land-cover and land-use change in a Mediterranean landscape: A spatial analysis of driving forces integrating biophysical and human factors. Applied Geography, 28(3), 189-209.

Sharma, L., Pandey, P.C. \& Nathawat, M. (2012). Assessment of land consumption rate with urban dynamics change using geospatial techniques. Journal of Land Use Science, 7(2), 135-148.

Song, W., Deng, X., Yuan, Y., Wang, Z. \& Li, Z. (2015). Impacts of land-use change on valued ecosystem service in rapidly urbanized North China Plain. Ecological Modelling, 318, 245-253.

Srivastava, P.K, Han, D., Rico-Ramirez, M.A., Bray, M. \& Islam, T. (2012). Selection of classification techniques for land use/land cover change investigation. Advances in Space Research, 50, 1250-1265.

Stojković, S., Đurđić, S. \& Anđelković, G. (2015). Application of Multi-Criteria Analysis and GIS in Ecotourism Development (Case Study: Serbian Danube Region). Bulletin of the Serbian Geographical Society, 95(1), 51-66.

Sun, X. \& Li, F. (2017). Spatiotemporal assessment and trade-offs ofmultiple ecosystem services based on land use changes in Zengcheng, China. Science of the Total Environment, 609, 1569-1581. 
Townshend, J., Justice, C., Li, W., Gurney, C. \& McManus, J. (1991). GLC classification by remote sensing: present capabilities and future possibilities. Remote Sens. Environ., 35, 243-255.

Van der Sluis, T., Pedrolia, ,B., Kristensen, S.B.P., Cosor, G.L. \& Pavlis, E. (2016). Changing land use intensity in Europe - Recent processes in selected case studies. Land Use Policy, 57, 777-785.

Vigl, L.E., Tasser, E., Schirpke, U. \& Tappeiner, U. (2017). Using land use/ land cover trajectories to uncover ecosystem service patterns across the Alps. Reg Environ Change, 17, 2237-2250.

Vujadinović, S., Šabić, D. \& Gajić, M. (2016). Local government in Serbia: between legislation and practice. Collection of Papers - Faculty of Geography at the University of Belgrade, 64, 73-90.

Waser, L.T. \& Schwarz, M. (2006). Comparison of large-area land cover products with national forest inventories and CORINE land cover in the European Alps. International Journal of Applied Earth Observation and Geoinformation, 8(3), 196-207.

Yilmaz, R. (2010). Monitoring land use/land cover changes using CORINE land cover data: a case study of Silivri coastal zone in Metropolitan Istanbul. Environ Monit Assess, 165, 603-615.

Живковић, Д. \& Јовановић, J. (2007). Картографска транслација геопросторних података. Зборник радова Географског факултета Универзитета у Београду, 55, 175-184.

Килибарда, М., Протић, Д. \& Несторов, И. (2010). Примена Google Maps Api сервиса за израду Web карте информација изведених из Corine база података о земљишном покривачу. Гласник Српског географрckог друштва, 90(4), 103-114.

Просторни план општине Стара Пазова до 2025. године (2011). Скупштина општине Стара Пазова, АП Војводина, РС.

Ромелић, J. (2005). Стара Пазова. У С. Стаменковић (ур.), Географска енизиклопедија насеља Србије - Војводина (стр. 330-337). Београд: Географски факултет Универзитета у Београду.

Ћурчић, С. (2000). Насеља Срема - Географске карактеристике. У Р. Давидовић (ур.), Регионално географска проучавана Војводине (стр. 141152). Нови Сад: Природно математички факултет. 
Ћурчић, С., Милошевић. П. \& Прица, Р. (1989). Стара Пазова. У М. Малетић (ур.), Социјалистичка Република Србија - Социјалистичка АП Војводина (стр. 575-579). Београд: Књижевне новине.

http://land.copernicus.eu/pan-european/corine-land-cover, Downloaded September 04, 2017.

http:/ /www.geosrbija.rs. Accessed September 08, 2017.

https://www.google.rs/maps. Accessed September 14, 2017.

http://www.stat.gov.rs. Accessed September 08, 2017. 